\title{
Study on Crop Losses due to COVID-19 Lockdown Period in Nagaon district of Assam
}

\author{
DINESH HAZARIKA ${ }^{1}$, BINOD KALITA ${ }^{*}$, NASEEMA RAHMAN ${ }^{2}$ AND P C SARMAH ${ }^{3}$
}

\begin{abstract}
An online survey was performed among the different categories of farm households in Nagaon district, Assam. Out of 300 cropped based agricultural farm households, 151 nos. of farmers were selected randomly and were grouped in accordance to their operational holdings viz. marginal ( $<1$ ha), Small (1.01 to 2 ha), Medium ( 2.01 to 4 ha) and large ( $>4.01 \mathrm{ha})$. The necessary information was collected through their WhatsApp's, messages and telephonic conversation from different 43 revenue villages. With a view to estimate the loss of crops cultivated during Lockdown Period (24 ${ }^{\text {th }}$ March, 2020 to $18^{t h}$ April, 2020) due to COVID 19 and determines the loss percentage of different crop enterprises for each group of farmers with district as a whole. After analyzing the received information, it was found that large farms suffered maximum $(71.69 \%)$ due to small tea garden and betel vine and medium farms incurred loss of about $61.33 \%$. the overall loss of crops was $68.96 \%$. The loss was found to be chiefly due to acute shortage of field labourers following COVID 19 restrictions during Lock Down period 1. As a result of which plucking, harvesting, marketing etc. all are at halt.
\end{abstract}

KEYWORDS

WhatsApp, operational holdings, Covid-19
ARTICLE INFO

\begin{tabular}{lll} 
Received on & $:$ & $28 / 04 / 21$ \\
Accepted on & $:$ & $27 / 06 / 21$ \\
Published online & $:$ & $30 / 06 / 21$ \\
\hline
\end{tabular}

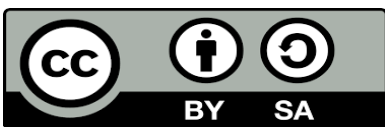

\section{INTRODUCTION}

$\mathrm{T}$ The world has passed through many global pandemics from time immemorial. The Covid-19 one of the global pandemics is not a new urgency for humankind, which has abruptly brought significant impacts on public health and the global economy (Thapa et al, 2020). Nevertheless, as per WHO (2020) has officially declared outburst of Covid-19 as a global pandemic (Vanelli and M, 2020). The pandemic was escalating very rapidly worldwide because of which protection measure cost for humans was inflecting and as a result, the world's economic activities were suspended (Singh et al, 2020). According to the IMF (2020), it has been estimated that the global economy is projected to reduce sharply by -3 percent in 2020, which is much worse than 2008-2009. It has been also assumed that there will be a rise in the global economy by 2021 by 5.6 percent as all the activities will normalize assisted by policy makers.

The official announcement of COVID-19 as a global pandemic on March 11, 2020 by WHO, the world economy has abruptly declined, billions of people were in lockdown, maintaining self-isolation. The lockdown to curb the spread of Covid19 has severely hampered India's agricultural sector, which currently contributes $16-17 \%$ of the GDP. India hosts nearly one fourth of the world's farmers and possess $48 \%$ of world's arable land. The country has made significant advances in many off-farm sectors such as service sector, industrial production etc. but agriculture continues to be the lifeline of the nation, especially for the $64 \%$ Indians living in rural areas. More than half the farmers who harvested their crops suffered a lower yield during the nationwide lockdown, compared to the last season of sowing the same crop, revealed a survey of 1,500 farmers in 200 districts across 12 states.

Table 1: The Breakup of the Farm size

\begin{tabular}{lll}
\hline Farm size & No of farmers & Average area per farm (ha) \\
Marginal & 63 & 0.51 \\
Small & 54 & 1.34 \\
Medium & 23 & 2.31 \\
Large & 11 & 1.01 \\
Total & $\mathbf{1 5 1}$ & 2.05 \\
\hline
\end{tabular}

The lockdown to curb the spread of the novel coronavirus disease (COVID-19) also forced 55 per cent of the farmers to store their crops as they were unable to sell them. The survey aimed to evaluate the impact of the lockdown on agricultural production and livelihood was conducted by the Harvard TH Chan School of Public Health, Public Health Foundation of India and Centre for Sustainable Agriculture from May 3 to May 15, 2020.Losses for 40 per cent of the farmers who experienced a yield loss, occurred from a lack of labour, storage or transport options, said the survey. Weather was also cited

\footnotetext{
1 Principal Scientist, Regional Agricultural Research Station, AAU, Shillongani, Nagaon, 782002, Assam, India

2 Scientist, Regional Agricultural Research Station, AAU, Shillongani, Nagaon, 782002, Assam, India

${ }^{3}$ Chief Scientist, Regional Agricultural Research Station, AAU, Shillongani, Nagaon, 782002, Assam, India

*Corresponding author email: binod_kalita05@rediff.com
} 
Table 2: Crop loss Assessment during Lockdown period 1 for Marginal farms in Nagaon District (Nos. of Farmer=63)

\begin{tabular}{|c|c|c|c|c|c|c|c|c|c|c|c|}
\hline crops & $\begin{array}{l}\text { No. of } \\
\text { farmers }\end{array}$ & $\begin{array}{l}\text { Area } \\
\text { (ha) }\end{array}$ & $\begin{array}{l}\text { Total } \\
\text { Pro- } \\
\text { duction } \\
\text { (q) }\end{array}$ & $\begin{array}{l}\text { Family } \\
\text { con- } \\
\text { sump- } \\
\text { tion } \\
\text { (q) }\end{array}$ & $\begin{array}{l}\text { Marketab } \\
\text { surplus } \\
\text { (q) }\end{array}$ & $\begin{array}{l}\text { eMarketed } \\
\text { surplus } \\
\text { (q) }\end{array}$ & $\begin{array}{l}\text { Market } \\
\text { Price } \\
(\text { Rs/q) }\end{array}$ & $\begin{array}{l}\text { Value } \\
\text { of Mar- } \\
\text { ketable } \\
\text { Surplus } \\
\text { (Rs) }\end{array}$ & $\begin{array}{l}\text { Value } \\
\text { of Mar- } \\
\text { keted } \\
\text { surplus } \\
\text { (Rs) }\end{array}$ & $\begin{array}{l}\text { Loss } \\
\text { (Rs) }\end{array}$ & $\%$ Loss \\
\hline Tomato & 18 & 1.52 & 213 & 11.00 & 202.00 & 21.00 & 1000 & 202000 & 21000 & 181000 & 89.60 \\
\hline Chilli & 21 & 0.42 & 6 & 0.05 & 5.95 & 1.50 & 2000 & 11900 & 3000 & 8900 & 74.79 \\
\hline okra & 9 & 0.35 & 13 & 0.06 & 12.94 & 4.00 & 2000 & 25880 & 8000 & 17880 & 69.08 \\
\hline capsicum & 15 & 0.60 & 10 & 0.05 & 9.95 & 3.10 & 3000 & 29850 & 9300 & 20550 & 68.84 \\
\hline Brinjal & 12 & 0.98 & 39 & 2.00 & 37.00 & 15.00 & 1000 & 37000 & 15000 & 22000 & 59.45 \\
\hline $\begin{array}{l}\text { Bottle } \\
\text { gourd }\end{array}$ & 9 & 0.63 & 22 & 1.50 & 20.50 & 5.50 & 1500 & 30750 & 8250 & 22500 & 73.17 \\
\hline Cabbage & 25 & 1.75 & 147 & 7.00 & 140.00 & 75.00 & 1000 & 140000 & 75000 & 65000 & 46.42 \\
\hline \multirow[t]{2}{*}{ Cauliflower } & 25 & 1.75 & 92 & 5.00 & 87.00 & 36.00 & 1800 & 156600 & 64800 & 91800 & 58.62 \\
\hline & 134 & 8.00 & & & & & & 633980 & 204350 & 429630 & \\
\hline
\end{tabular}

Total $\%$ of Loss $=($ Total loss/Value of Marketable Surplus $)=633980 / 429630 \times 100=\mathbf{6 7 . 7 6} \%$

as a reason for the loss in yield by 80 per cent of the farmers. Around 30 per cent of them were unable to harvest their crops because of issues related to the lockdown, said the survey. Out of the 63 per cent farmers who could harvest their crops, 22 per cent had to store their crop due to lockdown related issues. Around 12 per cent farmers were still trying to sell their crop, while 44 per cent farmers managed to sell their produce. A study was undertaken by Regional Agricultural Research Station, AAU, Shillongani, Nagaon to estimate the loss of crops cultivated during Lockdown Period 1 in different categories of farmers in the district as well as evaluate the loss percentage of different crops for each group of farmers and district as a whole.

\section{MATERIALS AND METHODS}

The study was based on farm level information pertaining to the Lockdown Period 1(23 ${ }^{\text {rd }}$ March, 2020 to $20^{t h}$ April, 2020) in Nagaon district. Out of the total villages of 1412,

Table 3: Crop loss Assessment during Lockdown period 1 for Small farms in Nagaon District $($ Nos. of Farmer $=54)$

\begin{tabular}{|c|c|c|c|c|c|c|c|c|c|c|c|}
\hline Crops & $\begin{array}{l}\text { No. of } \\
\text { farmers }\end{array}$ & $\begin{array}{l}\text { Area } \\
\text { (ha) }\end{array}$ & $\begin{array}{l}\text { Total } \\
\text { Produ- } \\
\text { ction } \\
\text { (q) }\end{array}$ & $\begin{array}{l}\text { Family } \\
\text { consu- } \\
\text { mption } \\
\text { (q) }\end{array}$ & $\begin{array}{l}\text { Marke- } \\
\text { table } \\
\text { surplus } \\
\text { (q) }\end{array}$ & $\begin{array}{l}\text { Marke- } \\
\text { ted } \\
\text { surplus } \\
\text { (q) }\end{array}$ & $\begin{array}{l}\text { Market } \\
\text { Price } \\
\text { (Rs/q) }\end{array}$ & $\begin{array}{l}\text { Value of } \\
\text { Marketable } \\
\text { Surplus } \\
\text { (Rs) }\end{array}$ & $\begin{array}{l}\text { Value of } \\
\text { Marketed } \\
\text { surplus (Rs) }\end{array}$ & $\begin{array}{l}\text { Loss } \\
\text { (Rs) }\end{array}$ & $\begin{array}{l}\% \\
\text { Loss }\end{array}$ \\
\hline Tomato & 20 & 3.60 & 63 & 3.15 & 59.85 & 5.98 & 1000 & 59850 & 5980 & 53870 & 90.00 \\
\hline Chilli & 16 & 2.56 & 15 & 0.75 & 14.25 & 2.34 & 2000 & 29500 & 4680 & 24820 & 84.13 \\
\hline okra & 27 & 2.97 & 40 & 8.00 & 32.00 & 8.00 & 2000 & 64000 & 16000 & 48000 & 75.00 \\
\hline capsicum & 18 & 1.62 & 18 & 0.36 & 17.64 & 3.50 & 3000 & 52920 & 10500 & 42420 & 80.15 \\
\hline Brinjal & 30 & 7.80 & 46 & 1.92 & 44.08 & 5.65 & 1000 & 44080 & 5650 & 38430 & 87.18 \\
\hline $\begin{array}{l}\text { Bottle } \\
\text { gourd }\end{array}$ & 30 & 3.90 & 44 & 2.20 & 41.80 & 21.64 & 1500 & 62700 & 32460 & 30240 & 48.30 \\
\hline Cabbage & 35 & 4.55 & 70 & 7.00 & 63.00 & 15.50 & 1000 & 63000 & 15500 & 47500 & 75.39 \\
\hline Cauliflower & 35 & 4.55 & 53 & 2.65 & 50.35 & 15.68 & 1800 & 90630 & 28224 & 62406 & 68.85 \\
\hline Pointed & 10 & 1.30 & 12 & 0.25 & 11.75 & 2.25 & 1200 & 14100 & 2700 & 11400 & 80.85 \\
\hline \multicolumn{12}{|l|}{ gourd } \\
\hline $221 \quad 32.85$ & & & & & 480780 & 359066 & & & & & \\
\hline
\end{tabular}

Total $\%$ of Loss $=($ Total loss/Value of Marketable Surplus $)=359066 / 480780 \times 100=74.68 \%$ 
Table 4: Crop loss Assessment during Lockdown period 1 for Medium farms in Nagaon District (Nos. of Farmer =23)

\begin{tabular}{|c|c|c|c|c|c|c|c|c|c|c|c|}
\hline crops & $\begin{array}{l}\text { No. of } \\
\text { farm- } \\
\text { ers }\end{array}$ & $\begin{array}{l}\text { Area } \\
\text { (ha) }\end{array}$ & $\begin{array}{l}\text { Total } \\
\text { Produc } \\
\text { tion }(q)\end{array}$ & $\begin{array}{l}\text { Family } \\
\text { consump } \\
\text { tion (q) }\end{array}$ & $\begin{array}{l}\text { Mar- } \\
\text { ketable } \\
\text { surplus } \\
\text { (q) }\end{array}$ & $\begin{array}{l}\text { Mar- } \\
\text { keted } \\
\text { surplus } \\
\text { (q) }\end{array}$ & $\begin{array}{l}\text { Market } \\
\text { Price } \\
\text { (Rs/q) }\end{array}$ & $\begin{array}{l}\text { Value of } \\
\text { Marketable } \\
\text { Surplus (Rs) }\end{array}$ & $\begin{array}{l}\text { Value of } \\
\text { Marketed } \\
\text { surplus (Rs) }\end{array}$ & $\begin{array}{l}\text { Loss } \\
\text { (Rs) }\end{array}$ & $\begin{array}{l}\% \\
\text { Loss }\end{array}$ \\
\hline Tomato & 5 & 0.18 & 65.00 & 3.20 & 61.80 & 12.36 & 1000 & 61800 & 12360 & 49440 & 80.00 \\
\hline $\begin{array}{l}\text { Pump- } \\
\text { kin }\end{array}$ & 5 & 0.18 & 12.00 & 1.54 & 10.46 & 9.41 & 1000 & 10460 & 9410 & 1050 & 10.03 \\
\hline Chilli & 11 & 0.13 & 15.60 & 1.69 & 13.91 & 2.39 & 2000 & 27820 & 4780 & 23040 & 82.81 \\
\hline $\begin{array}{l}\text { Cucum- } \\
\text { ber }\end{array}$ & 8 & 0.39 & 20.35 & 4.23 & 24.58 & 8.85 & 1000 & 24580 & 8850 & 15730 & 63.99 \\
\hline $\begin{array}{l}\text { Brin- } \\
\text { jal }\end{array}$ & 16 & 0.26 & 70.00 & 3.51 & 66.49 & 23.40 & 1000 & 66490 & 23400 & 43090 & 64.80 \\
\hline $\begin{array}{l}\text { Bitter } \\
\text { gourd }\end{array}$ & 7 & 0.13 & 46.00 & 2.10 & 43.90 & 19.75 & 3000 & 131700 & 59250 & 72450 & 55.01 \\
\hline $\begin{array}{l}\text { Bot- } \\
\text { tle } \\
\text { gourd }\end{array}$ & 12 & 0.13 & 47.00 & 7.00 & 40.00 & 25.50 & 1500 & 60000 & 38250 & 21750 & 36.25 \\
\hline $\begin{array}{l}\text { Cab- } \\
\text { bage }\end{array}$ & 13 & 0.26 & 90.00 & 9.78 & 80.22 & 23.64 & 1000 & 80220 & 23640 & 56580 & 70.53 \\
\hline Cauliflor & wher & 0.26 & 55.00 & 4.13 & 50.87 & 21.76 & 1800 & 91566 & 39168 & 52398 & 57.22 \\
\hline $\begin{array}{l}\text { Black } \\
\text { gram }\end{array}$ & 6 & 0.65 & 1.67 & 0 & 1.67 & 1.67 & 5000 & 8350 & 8350 & 0 & 0 \\
\hline $\begin{array}{l}\text { Water } \\
\text { melon }\end{array}$ & 8 & 0.13 & 96.00 & 6.58 & 89.42 & 26.45 & 1200 & 107304 & 31740 & 75564 & 70.42 \\
\hline Total & 101 & 2.70 & & & & & & 670290 & & 411092 & \\
\hline
\end{tabular}

the list of the farmers was prepared by collecting the respective mobile phone nos., whatsapp nos., from different 43 revenue villages. The selected villages were linked either with APART (Assam Agribusiness and Transformation Project) or FLD (Front Line Demonstration) of different AICRP of Regional Agricultural Research Station, Assam Agricultural University, Shillongani, Nagaon, Assam. Phone nos. were listed village wise, all total 300 cropped based agricultural farmers. By randomizing a sample of 151 nos. farmers were selected. During the lock down period 1, crops in the cultivated field, total cultivable area, and present cropped area etc. relevant quarry were asked through telephone or they were able to communicate in whatsapp.The questionnaire were posted to the listed farmers in their respective mobiles and they were asked to answer with relevant information regarding total operational holdings, respective crops available during lockdown period, expected production and loss at that period . Farmers were directed to enlist the amount consume for family purposed, the quantity of produce actually sold and return received. After receiving the information, farmers were grouped according to their operational holdings viz. Marginal (>1 ha), Small (1.01 to 2.0 ha), Medium (2.01 to 4.0ha) and Large $(<4.01 \mathrm{ha})$ in table 1 and depicted in fig 1 . Data were analyzed in accordance to group size and overall to dis- trict. The information was categorized to marketed surplus after deducting family consumption and marketable surplus. The values of marketable and marketed surplus were calculated by multiplying with crop market price. Present production of cultivated crops of the farmers during the COVID 19 period were only considered. It means losses Respective losses were determined by deducting marketed surplus from marketable surplus. Total percentage of loss was calculated as Total Loss/Value of Marketable surplus x 100 .

Limitation of the study: The study is subject to the following limitations

1. The study is restricted to the Nagaon district only.

2. Time and communication are the factors, which have limited the size of the sample.

\section{RESULTS AND DISCUSSIONS}

\section{Marginal Farm}

howed the crops grown and loss incurred by the marginal farms. Out of the total 8 number of crops available in the farmers' field tomato was found to incur the highest loss $(89.60 \%)$ of the production during this period, as it is the most perishable and risky crop. Another crop, chilli recorded the second highest loser (74.79) grown by 21 respondents. Cole crops as Cabbage and cauliflower recorded46.42 and $58.62 \%$ loss in the lockdown period 1 and maximum farmers ( 25 each) culti- 
Table 5: Crop loss Assessment during Lockdown period 1 for Large farms in Nagaon District (Nos. of Farmer assessed =11)

\begin{tabular}{|c|c|c|c|c|c|c|c|c|c|c|c|}
\hline crops & $\begin{array}{l}\text { No. of } \\
\text { farm- } \\
\text { ers }\end{array}$ & $\begin{array}{l}\text { Area } \\
\text { (ha) }\end{array}$ & $\begin{array}{l}\text { Total } \\
\text { Produc } \\
\text { tion }(q)\end{array}$ & $\begin{array}{l}\text { Family } \\
\text { consump } \\
\text { tion }(q)\end{array}$ & $\begin{array}{l}\text { Mar- } \\
\text { ketable } \\
\text { surplus } \\
\text { (q) }\end{array}$ & $\begin{array}{l}\text { Mar- } \\
\text { keted } \\
\text { surplus } \\
\text { (q) }\end{array}$ & $\begin{array}{l}\text { Market } \\
\text { Price } \\
\text { (Rs/q) }\end{array}$ & $\begin{array}{l}\text { Value of } \\
\text { Marketable } \\
\text { Surplus (Rs) }\end{array}$ & $\begin{array}{l}\text { Value of } \\
\text { Marketed } \\
\text { surplus (Rs) }\end{array}$ & $\begin{array}{l}\text { Loss } \\
\text { (Rs) }\end{array}$ & $\begin{array}{l}\% \\
\text { Loss }\end{array}$ \\
\hline Tomato & 4 & 2.08 & 84.00 & 4.20 & 79.80 & 16.00 & 1000 & 79800 & 16000 & 63800 & 79.94 \\
\hline $\begin{array}{l}\text { Pump- } \\
\text { kin }\end{array}$ & 4 & 2.08 & 14.00 & 1.40 & 12.60 & 12.00 & 1000 & 12600 & 12000 & 600 & 4.75 \\
\hline $\begin{array}{l}\text { Brin- } \\
\text { jal }\end{array}$ & 8 & 3.12 & 40.00 & 2.00 & 38.00 & 8.60 & 1000 & 38000 & 8600 & 29400 & 77.36 \\
\hline $\begin{array}{l}\text { Bot- } \\
\text { tle } \\
\text { gourd }\end{array}$ & 5 & 0.65 & 23.00 & 2.60 & 20.40 & 7.50 & 1500 & 30600 & 11250 & 19350 & 63.23 \\
\hline $\begin{array}{l}\text { Ridge } \\
\text { gourd }\end{array}$ & 6 & 0.78 & 18.00 & 1.25 & 16.75 & 9.95 & 3000 & 50250 & 29850 & 20400 & 68.34 \\
\hline $\begin{array}{l}\text { Cab- } \\
\text { bage }\end{array}$ & 9 & 3.51 & 150.00 & 1.80 & 148.20 & 36.75 & 1000 & 148200 & 36750 & 111450 & 75.20 \\
\hline Cauliflor & wer & 3.90 & 140.00 & 3.20 & 136.80 & 56.85 & 1800 & 246240 & 102330 & 143910 & 58.44 \\
\hline $\begin{array}{l}\text { Black } \\
\text { gram }\end{array}$ & 3 & 3.00 & 9.00 & 0 & 9.00 & 9.00 & 5000 & 45000 & 45000 & 0 & 0 \\
\hline Squash & 4 & 0.64 & 22.00 & 0.80 & 21.20 & 9.65 & 1000 & 21200 & 9650 & 11550 & 54.48 \\
\hline $\begin{array}{l}\text { Water- } \\
\text { melon }\end{array}$ & 6 & 1.56 & 110.00 & 3.00 & 107.00 & 23.46 & 1200 & 128400 & 28152 & 100248 & 78.07 \\
\hline $\begin{array}{l}\text { Straw- } \\
\text { berry }\end{array}$ & 2 & 0.26 & 15.00 & 0.60 & 14.40 & 2.50 & 6000 & 86400 & 15000 & 71400 & 82.63 \\
\hline Banana & 7 & 3.50 & 11.50 & 1.45 & 10.05 & 4.62 & 2000 & 20100 & 9240 & 10860 & 54.02 \\
\hline $\begin{array}{l}\text { Betel } \\
\text { vine }\end{array}$ & 3 & 0.15 & $\begin{array}{l}120000 \\
\text { nos. }\end{array}$ & 300 nos & 110700 & 1530 & 8/20no & 44280 & 612 & 43668 & 98.61 \\
\hline Tea & 2 & 1.37 & 1.30 & 0 & 1.30 & 0 & 1500 & 195000 & 0 & 195000 & 100.00 \\
\hline Total & 73 & 26.60 & & & & & & 1146070 & & 821636 & 73 \\
\hline
\end{tabular}

vated these crops out of 63 farmers assessed. The overall loss of marketable surplus was $67.76 \%$ for the marginal farm.

\section{Small farm}

The findings were depicted in Table No. 3. It showed that crop cultivation, return and loss for the respondent small farmers. The respondent farmers cultivated 9 different rabi vegetables. Out of the total crops tomato recorded heavy loss $(90.00 \%)$ during the lockdown period 1 followed by Brinjal $(87.18 \%)$ of cropped area 7.80 ha. Most of the crop losses were

Total $\%$ of Loss $=($ Total loss/Value of Marketable Surplus $)$ $=377092 / 670290 \times 100=61.33 \%$

\section{Large farm}

The information was collected from 11 farmers of the study area. Those farmers cultivated not only rabi crops, some perennial crops like Banana, Betel vine and Tea cultivation also practiced (Table 5). In case of tea cultivation, the loss was $100 \%$ during the period. At that time plucking of tea leave more than $50 \%$ of the marketable surplus. The total loss for small farmers also raised to $74.68 \%$. Medium farm

Total number of farmers assessed was 23. They have grown 11 different crops with an area of 2.70 ha. These were shown in Table No. 4. From the table it was clear that crop chilli recorded the highest loss $(82.81 \%)$ followed by tomato $(80.00$ $\%)$. As 6 farmers cultivated Black gram (Pulse) and harvested later so there was no loss. Some other crop like pumpkin as cultivated might be stored for which loss was minimum $(10.03 \%)$.

was blocked and the effect of growth was stressed. Likewise, pumpkin had also less loss (4.70 \%) as mentioned for medium farm. Total percent loss for large farm was found to be $71.69 \%$. Total $\%$ of Loss $=($ Total loss/Value of Marketable Surplus $)=$ $821636 / 1146070 \times 100=\mathbf{7 1 . 6 9} \%$

\section{District as a whole}

A total of 151 farmers were communicated and data supplied were analyzed, shown in table No. 6. All total 19 different 
Table 6: Crop loss Assessment during Lockdown period 1 in Nagaon District Nos. of Farmer assessed =151

\begin{tabular}{|c|c|c|c|c|c|c|c|c|c|c|c|}
\hline crops & $\begin{array}{l}\text { Value } \\
\text { of } \\
\text { Mar- } \\
\text { ketable } \\
\text { Sur- } \\
\text { plus } \\
\text { (Rs.) }\end{array}$ & & & & & $\begin{array}{l}\text { Loss } \\
\text { (Rs.) }\end{array}$ & & & & & $\%$ Loss \\
\hline & Marginal & Small & Medium & Large & Total & Marginal & Small & Medium & Large & Total & \\
\hline Tomato & 202000 & 59850 & 61800 & 79800 & 403450 & 181000 & 53870 & 49440 & 63800 & 348110 & 86.28 \\
\hline Chilli & 11900 & 29500 & 27820 & & 69220 & 8900 & 24820 & 23040 & & 56760 & 81.99 \\
\hline Okra & 25880 & 64000 & & & 89880 & 17880 & 48000 & & & 65880 & 73.29 \\
\hline Capsicum & 29850 & 52920 & & & 82770 & 20550 & 42420 & & & 62970 & 76.07 \\
\hline Brinjal & 37000 & 44080 & 66490 & 38000 & 185570 & 22000 & 38430 & 43090 & 29400 & 132920 & 71.62 \\
\hline Bottle gourd & 30750 & 62700 & 60000 & 30600 & 184050 & 22500 & 30240 & 21750 & 19350 & 93840 & 50.98 \\
\hline Ridge gourd & & & & 50250 & 50250 & & & & 20400 & 20400 & 68.34 \\
\hline Cabbage & 140000 & 63000 & 80220 & 148200 & 431420 & 65000 & 47500 & 56580 & 111450 & 280530 & 65.02 \\
\hline Cauliflower & 156600 & 90630 & 91566 & 246240 & 585036 & 91800 & 62406 & 52398 & 143910 & 350514 & 59.91 \\
\hline Pointed gourd & & 14100 & & & 14100 & & 11400 & & & 11400 & 80.85 \\
\hline Pumpkin & & & 10460 & 12600 & 23060 & & & 1050 & 600 & 1650 & 7.15 \\
\hline Cucumber & & & 24580 & & 24580 & & & 15730 & & 15730 & 63.99 \\
\hline Squash & & & & 21200 & 21200 & & & & 11550 & 11550 & 54.48 \\
\hline Watermelon & & & 107304 & 128400 & 235704 & & & 75564 & 100248 & 175812 & 74.59 \\
\hline Banana & & & & 20100 & 20100 & & & & 10860 & 10860 & 54.02 \\
\hline Bitter gourd & & & 131700 & & 131700 & & & 72450 & & 72450 & 55.01 \\
\hline Black gram & & & 8350 & 45000 & 53350 & & & 00 & 00 & 00 & 00 \\
\hline Betel vine & & & & 44280 & 44280 & & & & 43668 & 43668 & 98.61 \\
\hline Strawberry & & & & 86400 & 86400 & & & & 71400 & 71400 & 82.63 \\
\hline Tea & & & & 195000 & 195000 & & & & 195000 & 195000 & 100.00 \\
\hline Total & 633980 & 480780 & 670290 & 1146070 & 2931120 & 429630 & 359086 & 411092 & 821636 & 2021444 & \\
\hline
\end{tabular}

crops were cultivated during the period. Perennial crops such as Betel vine and tea losses were 100 percent. In case of other crops tomato and pointed gourd recorded losses 86.28 and $80.85 \%$ respectively. So far vegetables were recorded losses were around $50.00 \%$. The total percentage loss for the district was found to be 68.96 .

Total $\%$ of Loss $=($ Total loss/Value of Marketable Surplus $)=$ $2021444 / 2931120 \times 100=68.96 \%$

\section{CONCLUSION}

The COVID 19 pandemic has affected the employment, worker migration as well the economic condition worldwide. The farmers, daily workers are mostly suffered, their working and productive force become negligible. Some subsistent farmers leave the agricultural activities and other farmers cultivated crops were unable to harvest their produce, whatever they harvested not able to market properly. Total loss of percentage, therefore, during the Lockdown Period 1 obtained to be $68.96 \%$ in the district as a whole. In case of cash crop tea suffered $100 \%$ and affected later on. Tomato, a highly perishable vegetable loss percentage was the highest among vegetables during that period. It is the responsibility of both state and central governments to come forward with helping hand to compensate the loss to a possible extent. Government may go for installing mini units of processing structure for pulse, rice, oilseeds etc. in different localities, developing infrastructure of commercial and tertiary sectors so far crop production is concerned.

\section{REFERENCES}

IMF. 2020. World Economic Outlook April 2020: The Great Lockdown. Retrieved on May 7, 2020 from International monetary fund https://www.imf.org/en/Publications/WEO/Issues/2020/ 
04/14/weo-april-2020. The Great Lockdown. Retrieved on May . Singh AK, Upadhyaya A, Kumari S, Sundaram PK and Jeet P. 2020. Role of Agriculture in making India $\$ 5$ trillion Economy under Corona Pandemic Circumstance. Journal of AgriSearch 6(02):5458. url: https://dx.doi.org/10.21921/jas.v6i02.18097. doi: 10. 21921/jas.v6i02.18097

Thapa S, sotang N, Adhikari J, Ghimire A, Limbu AK, Joshi A and Adhikari S. 2020. Impact of COVID-19 Lockdown on Agri- culture Education in Nepal: An Online survey. Pedagogical Research 5(4):em0076-em0076. url: https://dx.doi.org/10.29333/ pr/8465. doi: $10.29333 / \mathrm{pr} / 8465$

Vanelli CD and M. 2020. WHO declares COVID-19 a pandemic. Acta Biomedica 91:157-160.

WHO 2020. Situation Report-92 HIGHLIGHTS. . 